\title{
THE "Pétra Thymianón" FROM CHIOS; ITS VARIOUS TYPES AND THE CORRELATION OF THEIR CHARACTERISTICS WITH POTENTIAL APPLICATIONS
}

\author{
Laskaridis K. ${ }^{1}$, Patronis $\mathrm{M.}^{2}$ \\ Institute of Geology and Mineral Exploration (I.G.M.E.), "LITHOS" Laboratory, 1 Spyrou Louie Street, \\ Entrance C, Olympic Village, EL - 13677, Acharnae, Attica, Hellas \\ Tel.: +30-213-1337316, Fax: +30-213-1337463, E-mail: laskaridis@igme.gr
}

\begin{abstract}
Quarrying activity concerning "Pétra Thymianón" (= Thymianá Stone) is located in the homonymous region of Chios Island. This structural stone is experientially classified into four commercial types, bearing the quarrymen jargon names: "Hemískliri" (= Medium Hard), "Triandafylli" (= Rose Pink), "Malaki” (= Soft), "Melidjani" (= Purple). All those types consist mainly of carbonates. In a lesser extent, quartz, leafshaped minerals, and iron oxides - hydroxides occur. Geologically, Thymianá Stone is characterized as "Carbonaceous - Ferruginous Pelite". It is a sedimentary thinbedded rock with alternating layers of calcareous pelite and ultra fine-grained sandstone. Very low grade metamorphism is also present. The quarry production consists of blocks, being cut to slabs for paving and flooring and to shaped stone units for masonry. In this study, the physical mechanical properties of the various Thymianá Stone types have been determined according to the relevant EN Standards. Furthermore, the physical meaning of the quarrymen jargon has been established in connection with the stone types' quality characteristics and potential applications. Keywords: Ornamental Stones; Physical Mechanical Properties; Quarries
\end{abstract}

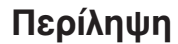

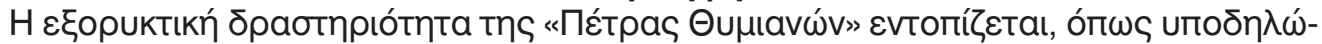

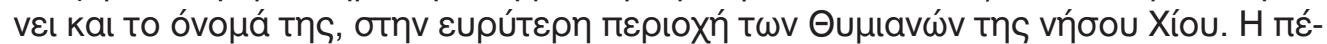

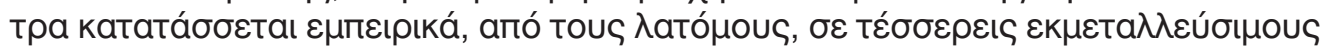

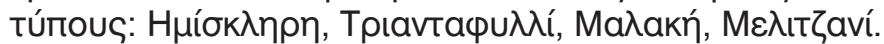

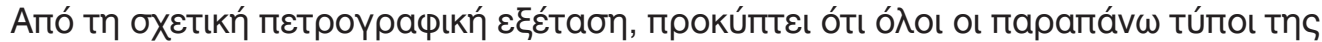

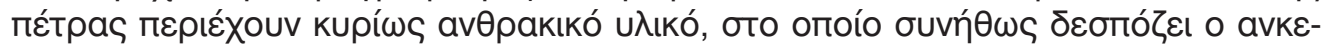

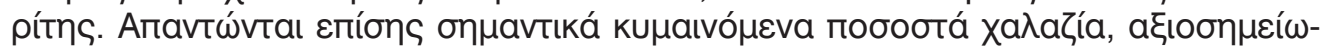

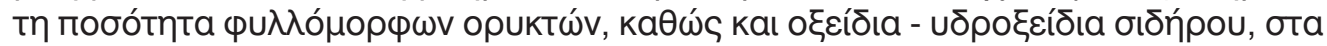

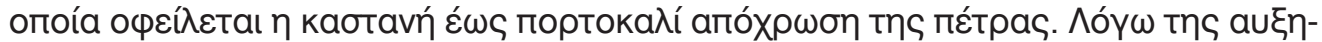

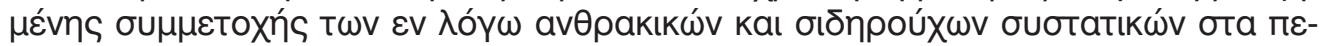

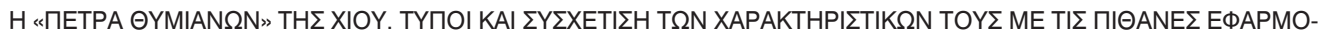
ГE $\Sigma$

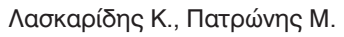




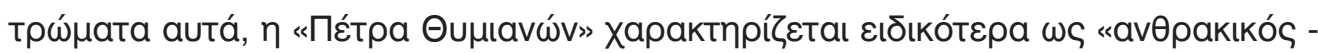

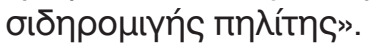

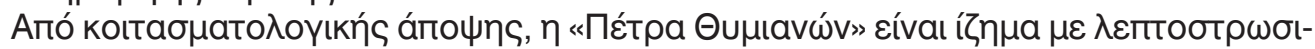

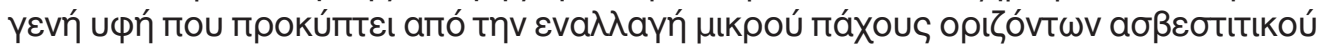

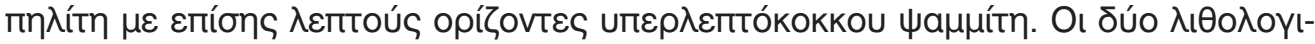

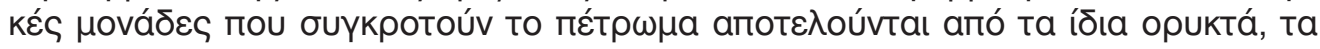

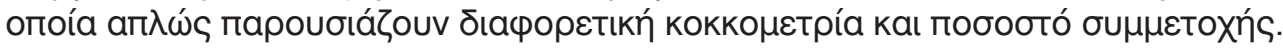

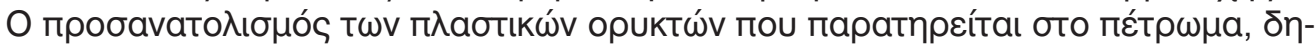

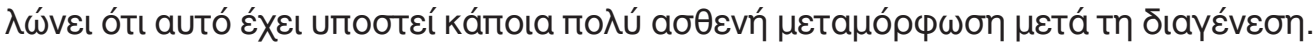

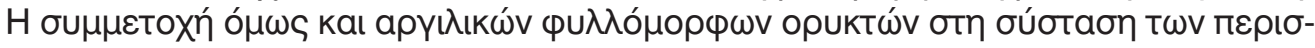

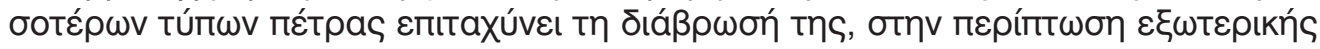

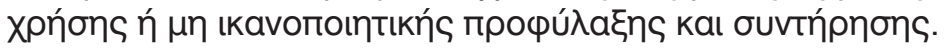

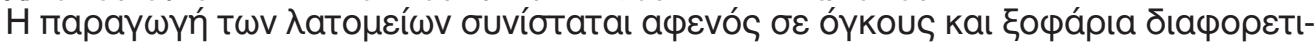

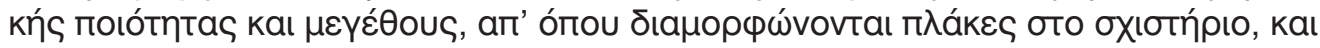

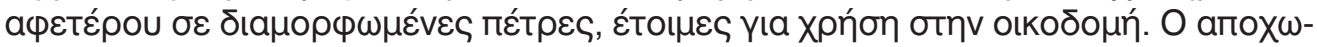

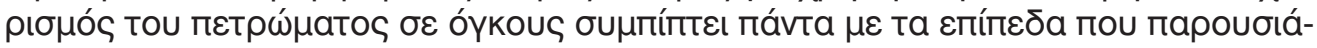

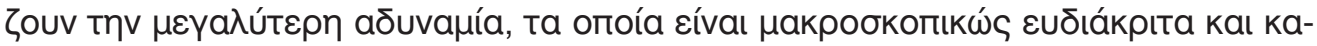

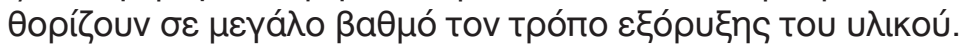

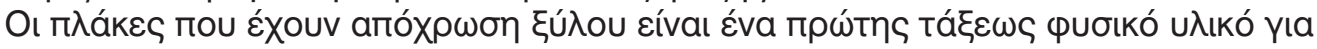

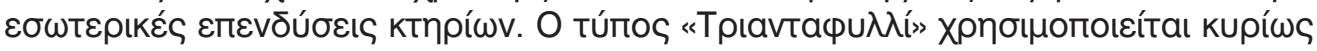

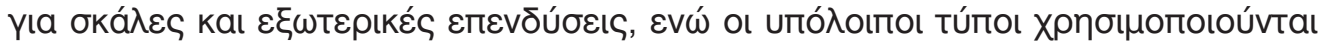

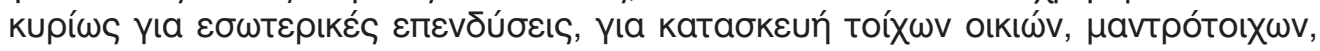

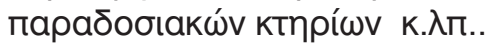

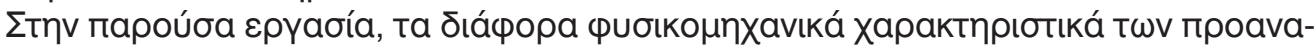

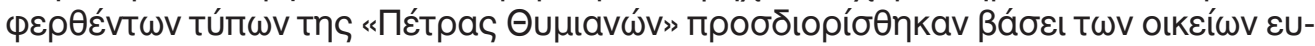

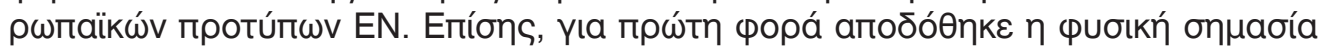

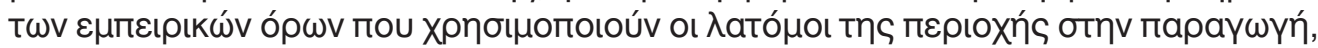
каӨ

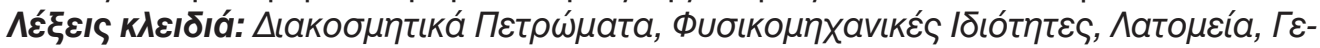
whoyía.

\section{Introduction}

The present study of the "Pétra Thymianón" (= Thymianá Stone) from Chios Island has been carried out in the frame of the "3rd Community Support Programme" EU funding scheme, as part of the Research Sub-Project titled "Evaluation of Quality Characteristics and Quantity Parameters for the Structural Stones of Greece. Administrative Study". Its objective was to record the existing quarrying situation, to determine the quality characteristics of the commercial stone types and to correlate them with potential applications.

Thymianá Stone was, and still is, one of the main "ingredients" in the architectural style of the island, as for example in the region of Kambos where the mansions are even today being built using this stone. Production activity takes place in small quarries located in the region of Thymianá village. Natives call those quarries "Korakés".

\section{Geology of the Area Under Study}

The area under study is located south of Chios town and includes the regions of 
Thymianá, Hermióni and Monastíri. The geological formations in the wider area date from the Upper Miocene to Pliocene (?) and are as follows (Besenecker, $\mathrm{H}$. et al., 1971):

a. Limestones of fresh water with intercalated marls with green clay and brow sand. Interbedded are thin layers of lignite, two small tuff horizons and locally oolitic beds.

b. Red clays and silts with green sandlenses.

c. Horizon of light pumiceous tuff.

d. Green sands and gravels.

e. Various conglomerates.

f. Ferruginous sandstones brownish to red, rich in silt, slightly calcareous, sometimes conglomeratic, with intercalated yellowish red silty marls. Fossils: internal molds of fresh-water Ostracods and Gas- tropods and carbonized plant remnants. g. Neogene undivided.

\section{Quarrying Activity}

At present, production of the Thymianá Stone (Fig. 1) is concentrated in three quarries located in the aforementioned ferruginous sandstone formations, near the "Platiá Rákhi" site of the wider Thymianá region. These are compact sedimentary rocks with relatively high iron oxides - hydroxides content and are classified as pelites, fine-grained sandstones and transitional lithologic facies.

The splitting of the stone in blocks of different type and thickness always follows the weakest anisotropy planes which are macroscopically visible and determine primarily the quarrying method to be employed.

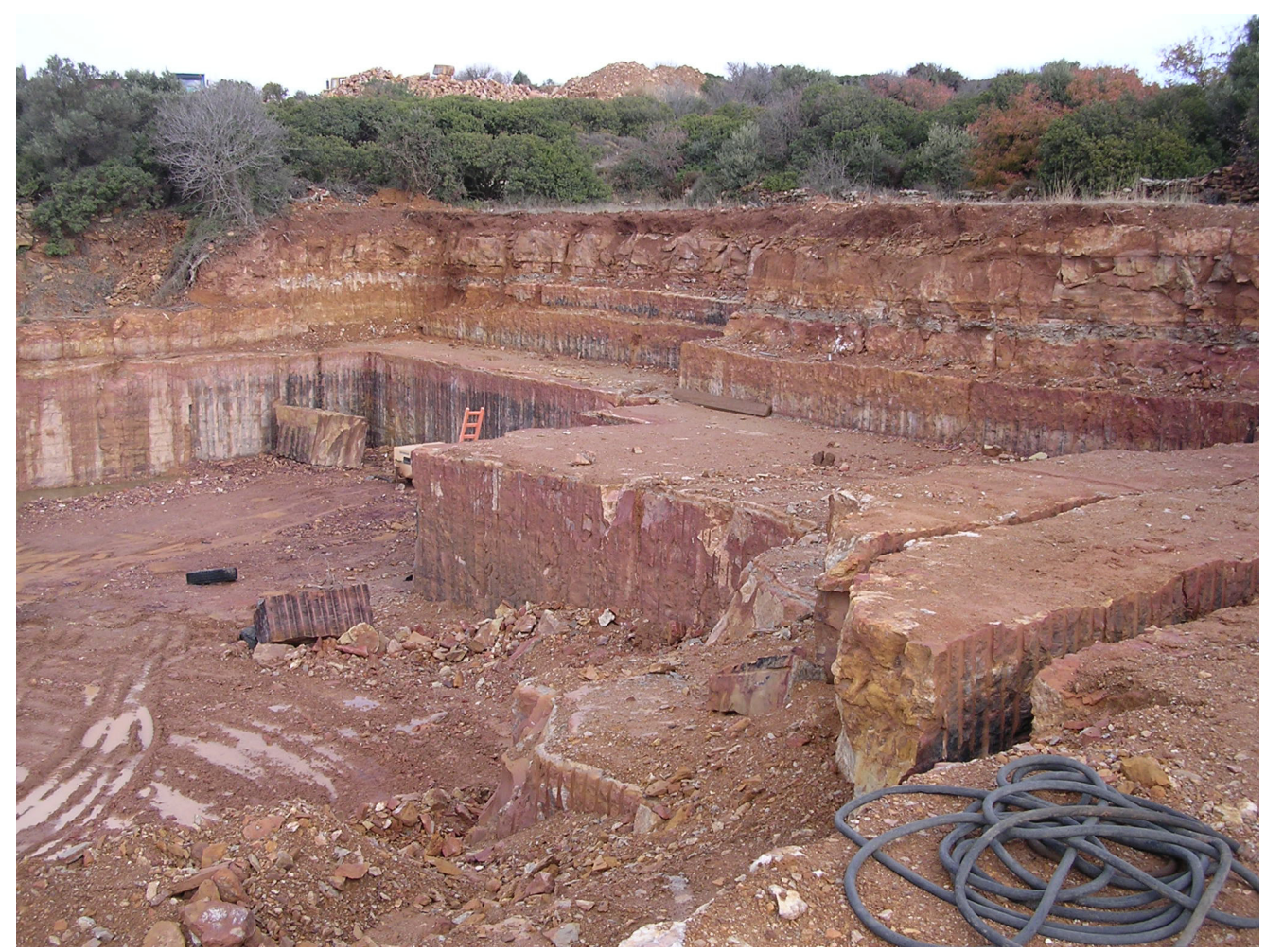

Fig. 1. Panoramic view of a "Pétra Thymianón" quarry.

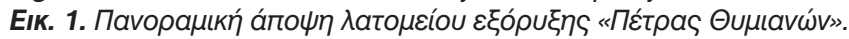


The schematic lithologic log of the quarry (Fig. 2) given in Tab. 1 shows the experiential classification of the stone into four commercial types, bearing the quar- rymen jargon names: "Hemískliri" (= Medium Hard), "Triandafylli" (= Rose Pink), "Malaki" (= Soft), "Melidjani" (= Purple (Papaioannou et al., 2006).

\begin{tabular}{|c|c|c|}
\hline $\begin{array}{l}\text { DEPTH } \\
\text { (m) }\end{array}$ & LITHOLOGY & DESCRIPTION \\
\hline 1,0 & 足 & Overburden. Thickness from 1.00 to $1.50 \mathrm{~m}$ \\
\hline 2,2 & 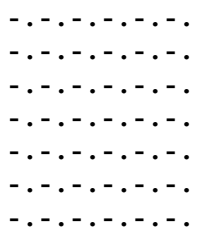 & "Póros". Friable stone of lesser quality. Thickness from 1.20 to $1.50 \mathrm{~m}$ \\
\hline 2,5 & 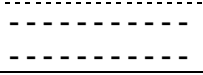 & Friable, non exploitable material. Thickness $\sim 0.30 \mathrm{~m}$ \\
\hline 3,25 & $\begin{array}{l}\text { ०००००००००० } \\
0000000000 \\
\circ 000000000 \\
0000000000\end{array}$ & Very hard material, only for masonry. Thickness $\sim 0.75 \mathrm{~m}$ \\
\hline 3,75 & 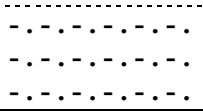 & "Hemískliri" (= Medium Hard). Thickness $\sim 0.50 \mathrm{~m}$ \\
\hline 4,75 & $\begin{array}{l}-1-1 \\
-1-1-1-1 \\
-1-1-1\end{array}$ & "Triandafylli" (= Rose Pink). Thickness $\sim 1.00 \mathrm{~m}$ \\
\hline 5,25 & 0000000000 & "Malaki" (= Soft). Upper sub-layer. Thickness $\sim 0.50 \mathrm{~m}$ \\
\hline 7,25 & 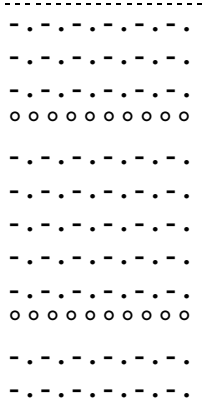 & "Malaki" (= Soft). Lower sub-layer. Thickness $\sim 2.00 \mathrm{~m}$ \\
\hline 7,75 & 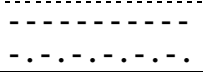 & "Melidjani" (= Purple). Thickness $\sim 0.50 \mathrm{~m}$ \\
\hline
\end{tabular}

Tab. 1. Schematic lithologic log of the Thymianá region.

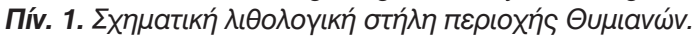




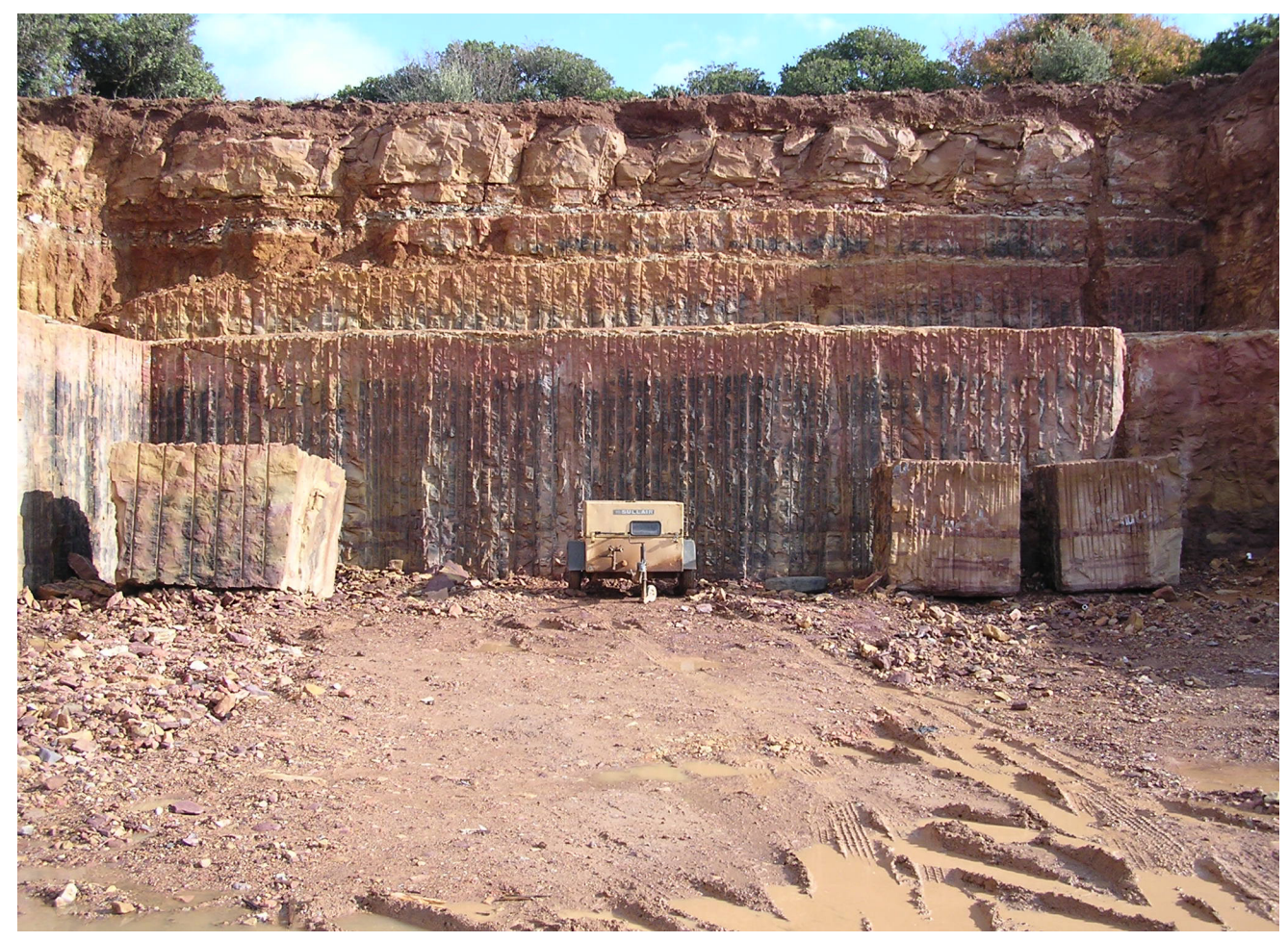

Fig. 2. Quarrying front showing the four commercial types of the Thymianá Stone.

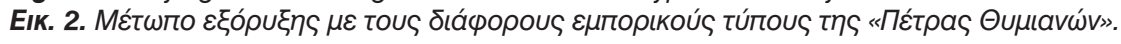
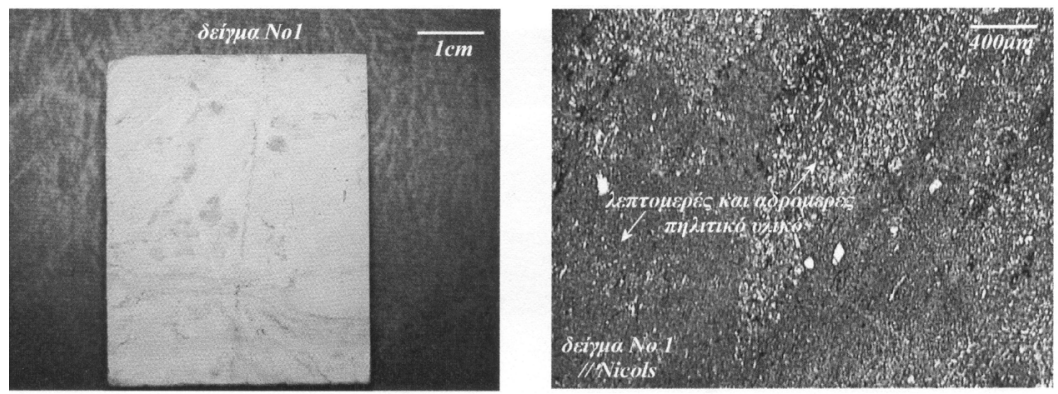

Fig. 3. "Hemískliri"; A fine-grained sediment of the pelite group and pelitic matrix with fine-grained material of slightly different grain size.

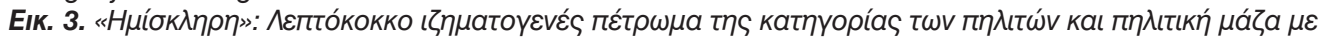

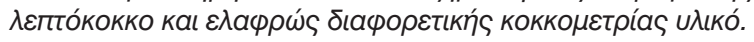

\section{Characterisation of the Various Stone Types}

\section{1. "Hemískliri"}

The colour of this stone type varies between yellowish and orange.

At sites, those two colours alternate. Petrographically, it is classified as a carbo- naceous - ferruginous pelite with a grain size not exceeding $0.03 \mathrm{~mm}$ (Fig. 3). This is a compact fine-grained clastic sediment, where ultra fine material $(2-10$ micron) is irregularly mixed with coarser material (2 - 30 micron) of the same mineralogical composition, including: 
- High quantities of carbonates, mainly ankerite and in a lesser extent dolomite and calcite;

- Various percentages of leaf-shaped minerals (muscovite - sericite, illite, chlorite, kaolinite);

- Quartz, as clastic grains;

- Iron oxides - hydroxides, either as grains and fine aggregates or as diffused stains, due to the increased percentage of which the stone assumes its orange and at sites lightly reddish colour;

- In minor quantities, complementary minerals (albite, pyrite) are found.

According to data from polarizing microscopic examination of samples, as well as from their XRD analyses, the qualitative and semi-quantitative mineralogical assay of the stone is presented in Tab. 2. Tab. 3 shows the physical mechanical properties of the "Hemískliri" type of the Thymianá Stone. It is noted that in specimens of this type having undergone

\begin{tabular}{|l|c|}
\hline \multicolumn{1}{|c|}{ Minerals } & $\begin{array}{c}\text { "Hemískliri" type. } \\
\text { Mineralogical assay, \% }\end{array}$ \\
\hline Quartz & 20 \\
\hline Ankerite & 43 \\
\hline Dolomite & 15 \\
\hline Calcite & 5 \\
\hline Muscovite - Sericite & 5 \\
\hline Illite & 2 \\
\hline Chlorite & 3 \\
\hline Kaolinite & 3 \\
\hline Goethite & 3 \\
\hline $\begin{array}{l}\text { Others (Albite, Pyrite, Hematite, } \\
\text { Limonite) }\end{array}$ & 1 \\
\hline
\end{tabular}

Tab. 2. "Hemískliri"; Semi-quantitative mineralogical assay (\%).

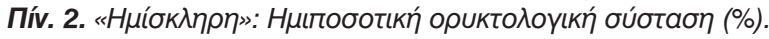

\begin{tabular}{|l|c|c|c|}
\hline \multicolumn{1}{|c|}{ PROPERTIES } & $\begin{array}{c}\text { "Hemískliri" } \\
\text { type }\end{array}$ & $\begin{array}{c}\text { "Triandafylli" } \\
\text { type }\end{array}$ & $\begin{array}{c}\text { "Malaki" } \\
\text { type }\end{array}$ \\
\hline Apparent density (EN 1936) & $2,220 \mathrm{~kg} / \mathrm{m}^{3}$ & $2,300 \mathrm{~kg} / \mathrm{m}^{3}$ & $2,210 \mathrm{~kg} / \mathrm{m}^{3}$ \\
\hline $\begin{array}{l}\text { Water absorption at atmospheric pressure } \\
\text { (EN 13755) }\end{array}$ & $8.4 \% \mathrm{wt}$. & $7.2 \% \mathrm{wt}$. & $8.0 \% \mathrm{wt}$. \\
\hline Open porosity (EN 1936) & $19.7 \% \mathrm{vol}$. & $18.7 \% \mathrm{vol}$. & $20.9 \% \mathrm{vol}$. \\
\hline Uniaxial compressive strength (EN 1926) & $75.9 \mathrm{MPa}$ & $94.1 \mathrm{MPa}$ & $40.7 \mathrm{MPa}$ \\
\hline $\begin{array}{l}\text { Uniaxial compressive strength after 24 frost } \\
\text { resistance cycles (EN 12371 / EN 1926) }\end{array}$ & $\begin{array}{c}85.0 \mathrm{MPa} \\
\text { from two intact } \\
\text { specimens) }\end{array}$ & $104.4 \mathrm{MPa}$ & $39.2 \mathrm{MPa}$ \\
\hline $\begin{array}{l}\text { Flexural strength under concentrated load } \\
\text { (EN 12372) }\end{array}$ & $13.0 \mathrm{MPa}$ & $19.8 \mathrm{MPa}$ & $12.6 \mathrm{MPa}$ \\
\hline Modulus of elasticity [Flexure] (EN 12372) & $4.5 \mathrm{GPa}$ & $4.6 \mathrm{GPa}$ & $4.1 \mathrm{GPa}$ \\
\hline Abrasion resistance (EN 14157 - Method A) & $33.3 \mathrm{~mm}$ & $27.9 \mathrm{~mm}$ & $34.3 \mathrm{~mm}$ \\
\hline Rupture energy [Impact] (EN 14158) & $3 \mathrm{Joule}$ & $3 \mathrm{Joule}$ & $2 \mathrm{Joule}$ \\
\hline
\end{tabular}

Tab. 3. Physical mechanical properties of the Thymianá Stone types (LITHOS Laboratory).

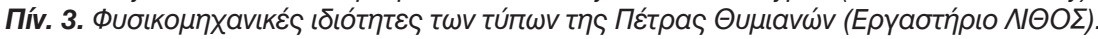


freeze - thaw cycles, splitting and separation across anisotropy planes has been observed. This was due to the presence of the clay minerals and their orientation across thin horizons (Fig. 4). This fact leads to the conclusion that "Hemískliri" is not suitable as an ornamental stone for external applications in climates with wide range temperature fluctuations.

\section{2. "Triandafylli"}

This type is quarried from the top 1-meter part of a layer with an average total thickness of 4 meters (Tab. 1). The stone is separated from the whole layer across a certain horizon, just above the ferruginous pelite with "geloid" texture at sites, by means of jackhammers, drilling bits, wedges or by using fuses along stylolites and across weak anisotropy planes. It has a reddish colour and it exhibits calcite veinlets, Mn oxide stains and open joints perpendicular to bedding. Due to the high hardness of this stone, the cutting of blocks is quite difficult and is performed in a direction vertical to bedding, hence parallel to the open joints.

Petrographically, it is classified as a carbonaceous - ferruginous fine-grained pelite with a grain size not exceeding $0.01 \mathrm{~mm}$ (Fig. 5).

According to data from XRD analyses of samples, the stone consists basically of a carbonate matrix, mainly ankerite and dolomite and, in a lesser extent, calcite.

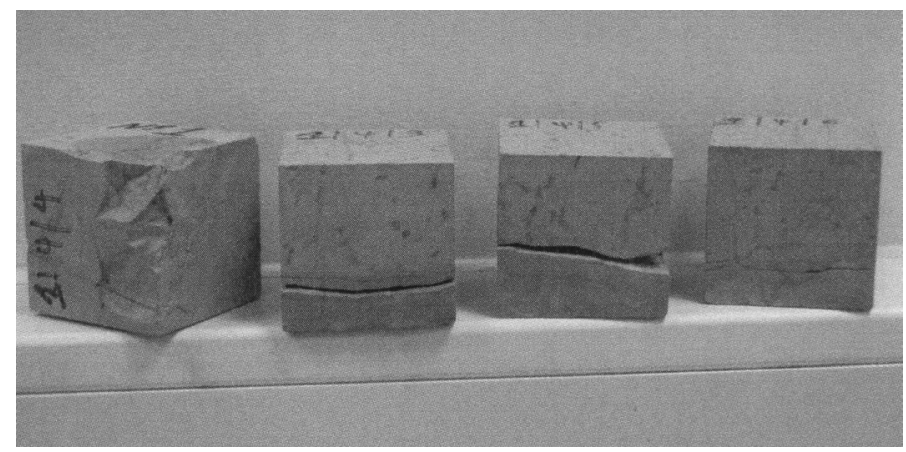

Fig. 4. "Hemískliri"; Splitting and separation across anisotropy planes in specimens having undergone freeze - thaw cycles.

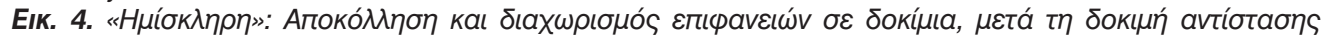

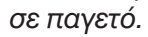
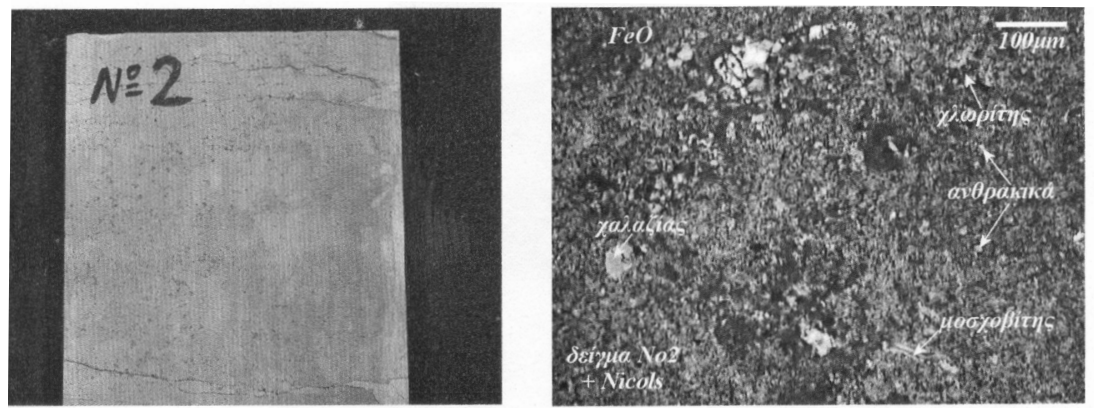

Fig. 5. "Triandafylli"; Reddish fine-grained pelite with high quantities of carbonates and iron oxides - hydroxides.

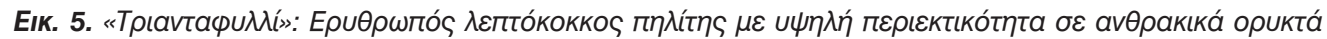

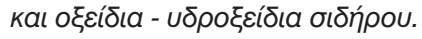


This material is complemented by significant amounts of ultra fine-grained iron oxides - hydroxides, diffused around the whole sample area and giving to the stone its reddish colour.

In some cases, dark ferruginous fine aggregates are present, together with coarse-grained carbonate material of secondary origin, usually within pores. The ultra fine-grained carbonate matrix also contains clastic quartz grains of small but varying size, as well as leafshaped minerals: mica (muscovite sericite), chlorite, and clay minerals (illite, kaolinite). The mineralogical assay (qualitative and semi-quantitative) of the stone is shown in Tab. 4.

The physical mechanical properties of the "Triandafylli" type of the Thymianá Stone can be seen in Tab. 3. It is noted that the increased quantities of ankerite and dolomite in this type of stone results in the higher degree of resistance (hardness) that it exhibits during cutting processes.

\section{3. "Malaki"}

This type of the Thymianá Stone follows immediately under the "Triandafylli" type, as a 2.5-meter thick layer in the same succession (Tab. 1), and is separated from it by means of jackhammers

\begin{tabular}{|l|c|}
\hline \multicolumn{1}{|c|}{ Minerals } & $\begin{array}{c}\text { "Triandafylli" type. } \\
\text { Mineralogical assay, \% }\end{array}$ \\
\hline Quartz & 10 \\
\hline Ankerite & 45 \\
\hline Dolomite & 25 \\
\hline Calcite & 5 \\
\hline Muscovite - Sericite & 3 \\
\hline Illite & 2 \\
\hline Chlorite & 2 \\
\hline Kaolinite & 3 \\
\hline Goethite - Hematite & 3 \\
\hline Others (Albite, Pyrite, Limonite) & 1 \\
\hline
\end{tabular}

Tab. 4. "Triandafylli"; Semi-quantitative mineralogical assay (\%).

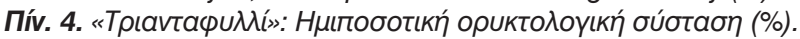
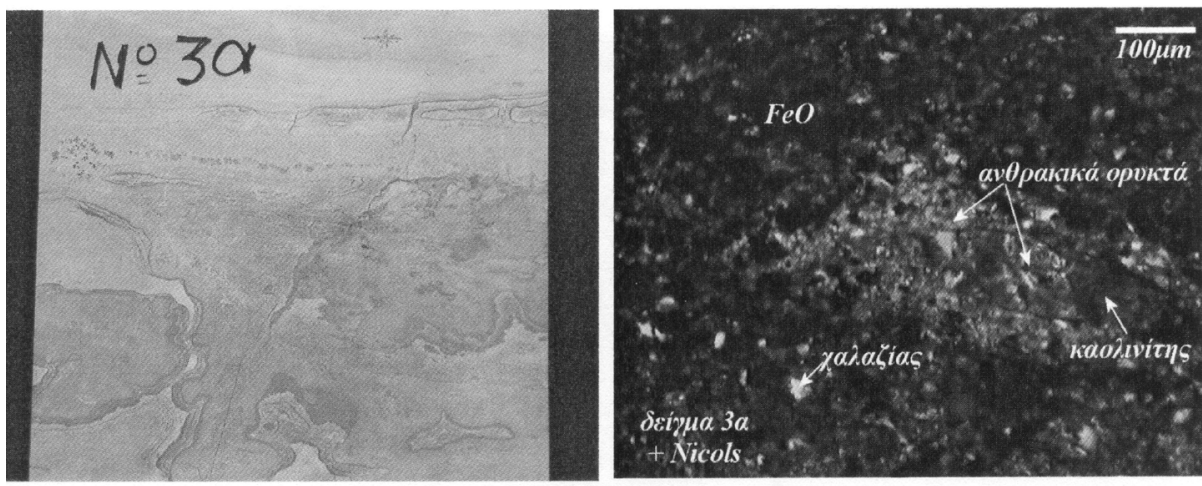

Fig. 6. "Malaki"; Reddish - orange pelite (due to iron oxides) with "geloid" texture at sites, rich in carbonates.

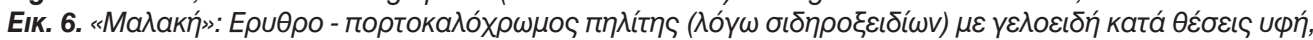

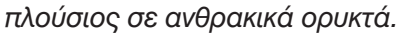


and wedges. Its colour varies (horizontally and vertically) from orange, light yellow, pinkish, nut-brown to beige. Significant percentages of quartz, carbonates and leaf-shaped minerals are present.

The upper 0.5 -meter thick part of this layer is a characteristic stone horizon, brown to orange in colour and at sites exhibiting alternations of concentric zones (Fig. 6) due to the presence of iron minerals. The coexistence of fineand medium-grained material gives to the stone a slightly inequigranular structure. This sub-layer is classified as a carbonaceous - ferruginous pelite with "geloid" texture at sites. Its grain size varies between 0.002 and $0.02 \mathrm{~mm}$ (Fig. 6). According to data from polarizing micro- scopic examination of samples, as well as from their XRD analyses, its main carbonate minerals are ankerite, dolomite and calcite, while its main iron ones include hematite, goethite, limonite and, in a lesser extent, pyrite. There are significant quantities of quartz, as well as of leaf-shaped minerals: muscovite - sericite, kaolinite, illite and chlorite. The mineralogical assay (qualitative and semiquantitative) of the stone is shown in Tab. 5.

The lower sub-layer (average thickness: 2 meters) is a medium- to coarsegrained carbonaceous - ferruginous pelite grading upward into fine-grained sandstone with compact to micro-porous texture (Fig. 7 ). Its grain size is not finer than $0.02 \mathrm{~mm}$ (Fig. 7).

\begin{tabular}{|l|c|c|}
\hline \multicolumn{1}{|c|}{ Minerals } & $\begin{array}{c}\text { "Malaki" type. Upper sub-layer. } \\
\text { Mineralogical assay, \% }\end{array}$ & $\begin{array}{c}\text { "Malaki” type. Lower sub-layer. } \\
\text { Mineralogical assay, \% }\end{array}$ \\
\hline Quartz & 32 & 45 \\
\hline Ankerite & 30 & 12 \\
\hline Dolomite & 15 & 6 \\
\hline Calcite & 5 & 10 \\
\hline Muscovite - Sericite & 4 & 6 \\
\hline Illite & 2 & 5 \\
\hline Chlorite & 2 & 7 \\
\hline Kaolinite & 3 & 5 \\
\hline Goethite - Hematite & 6 & 3 \\
\hline $\begin{array}{l}\text { Others (Albite, Pyrite, } \\
\text { Limonite) }\end{array}$ & 1 & 1 \\
\hline
\end{tabular}

Tab. 5. "Malaki"; Semi-quantitative mineralogical assay (\%).

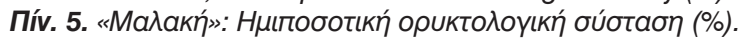
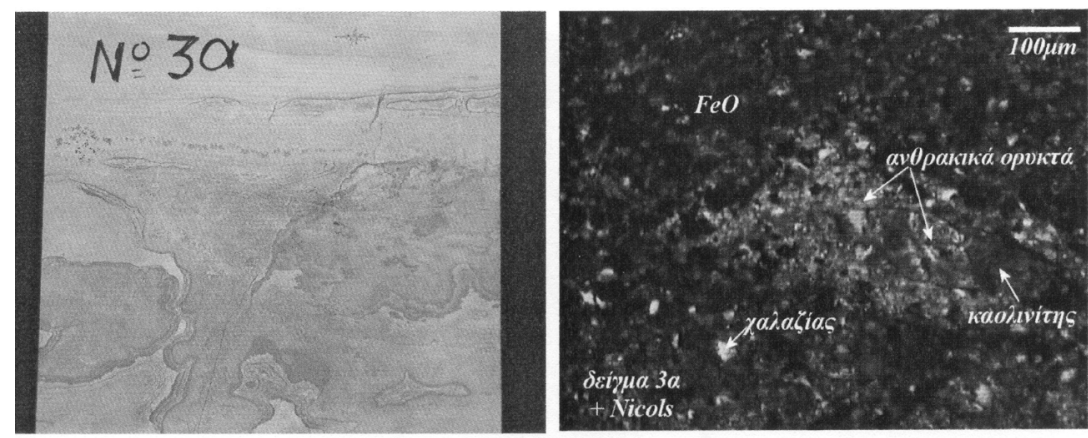

Fig. 7. "Malaki"; Pelite grading upward into fine-grained sandstone, with significant percentages of carbonates / iron oxides and with chlorite - calcite veinlets.

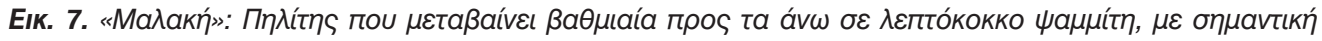

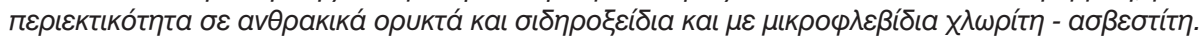


This rock is a clastic sediment with gradually changing grain size, between a medium- to coarse-grained pelite and a finegrained sandstone. Its composition is not different from that of the previous mentioned pelitic sediments. Thus, it is rich in carbonates and iron oxides - hydroxides. The latter give to the stone its orange colour. In addition, increased quantities of quartz are present together with leaf-shaped minerals, such as muscovite - sericite, illite, chlorite, kaolinite, as well as few grains of mica (albite) and of metallic minerals (oxidized pyrite). At sites, the rock shows bedding texture with micro-joints filled in a later phase with chlorite, calcite and ferruginous constituents. The mineralogical assay (qualitative and semi-quantitative) of the stone is shown in Tab. 5.

The physical mechanical properties of the "Malaki" type of the Thymianá Stone are given in Tab. 3. It is noted that almost all the values determined, such as uniaxial compressive strength, flexural strength under concentrated load, uniaxial compressive strength after frost resistance (freeze - thaw) cycles, open porosity, water absorption at atmospheric pressure, etc., fall marginally within or are out of the practical limits for most of its external applications as an ornamental stone.

\section{4. "Melidjani"}

This type of the Thymianá Stone is quarried from the bottom 0.5-meter thick part of the succession (Tab. 1). Its colour varies from nut-brown / red to bright purple and mauve, in the increased presence of iron oxides (Fig. 8). This is again a carbonaceous - ferruginous pelite with grain size not exceeding $0.02 \mathrm{~mm}$ (Fig. 8).

According to polarizing microscopic examination data and XRD analyses of samples, the stone is a medium-grained pelitic sediment with increased percentages of carbonate and ferruginous minerals. The main constituents are carbonates (ankerite, dolomite, calcite), followed by quartz, leaf-shaped minerals (muscovite, illite, chlorite, kaolinite) and iron oxides - hydroxides (hematite, goethite, limonite). The carbonates have various grain sizes, the ferruginous minerals are disseminated in the samples, while quartz and the leaf-shaped minerals tend to exhibit a parallel disposition (Fig. 8).
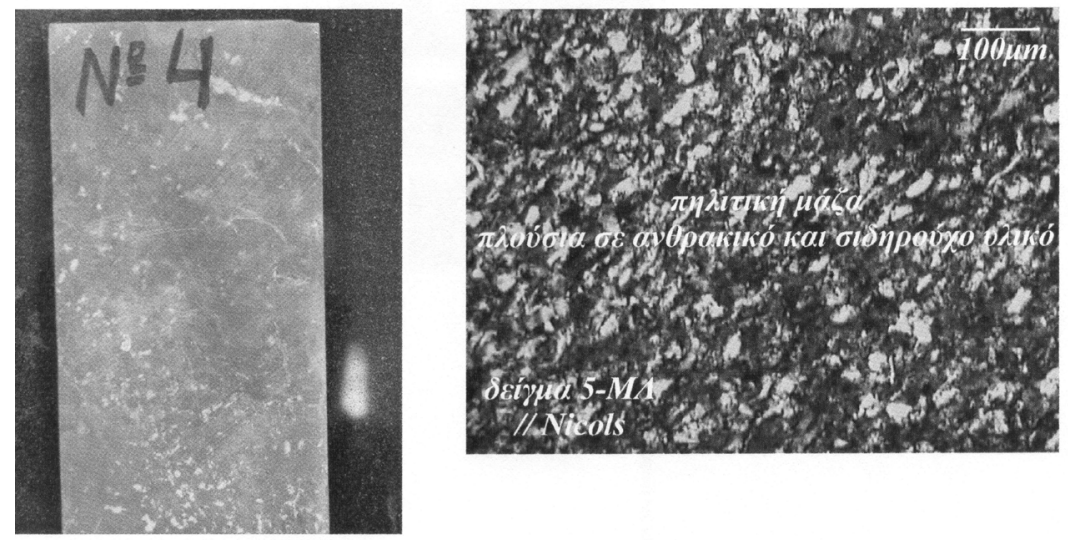

Fig. 8. "Melidjani"; A medium-grained carbonaceous - ferruginous pelite with carbonates, quartz, leaf-shaped and ferruginous minerals.

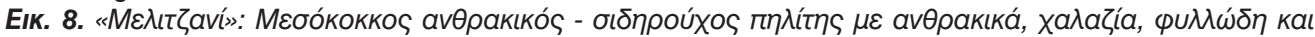

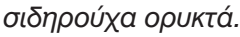


As complementary minerals, disseminated grains of partially oxidized pyrite, as well as biotite (mainly chloritized) are also present in the samples. The mineralogical assay (qualitative and semiquantitative) of the stone is shown in Tab. 6.

\section{Production - Treatment}

As already mentioned, production activities of the Thymianá Stone (Fig. 1) are concentrated in three privately owned quarries located near the "Platiá Rákhi" site of the wider Thymianá region. The equipment for quarrying, cutting, splitting and shaping of the stone consist of jackhammers, diamond wire-cutting, tracked shovels with hydraulic hammers, and tracked or wheeled loaders.

The Thymianá Stone is quarried in the form of blocks and unshaped blocks of varying quality and size, as well as of shaped stone units for masonry. The splitting of the stone always follows the weakest anisotropy planes which are macroscopically visible and crucial in determining the suitable quarrying method (Fig. 1). The exploitable quantity reaches 70 to $75 \%$ of the quarried one. Of the exploitable quantity, $15 \%$ are blocks being gangsaw-cut (in Athens) to slabs for various applications, while the rest is treated in factories on the island. The total annual production is:

- Blocks: 3,000 m3

- Unshaped blocks (for masonry units): $\sim$ 4,000 m3

- Slabs (all dimensions): 25,000 m2 Slabs with a "woody" colour are a topclass natural material for internal cladding applications. The "Triandafylli" type is mainly used for stairs and external cladding, while the rest commercial types go for internal cladding, house masonry, stone fences, traditional buildings, etc. (Fig. 9).

\begin{tabular}{|l|c|}
\hline \multicolumn{1}{|c|}{ Minerals } & $\begin{array}{c}\text { "Melidjani" type. } \\
\text { Mineralogical assay, \% }\end{array}$ \\
\hline Quartz & 30 \\
\hline Ankerite & 25 \\
\hline Dolomite & 10 \\
\hline Calcite & 10 \\
\hline Muscovite & 6 \\
\hline Illite & 5 \\
\hline Chlorite & 5 \\
\hline Kaolinite & 4 \\
\hline Goethite - Hematite & 4 \\
\hline $\begin{array}{l}\text { Others (Albite, Biotite, Pyrite, } \\
\text { Limonite) }\end{array}$ & 1 \\
\hline
\end{tabular}

Tab. 6. "Melidjani”; Semi-quantitative mineralogical assay (\%).

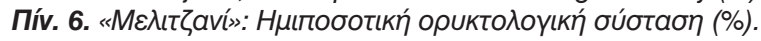



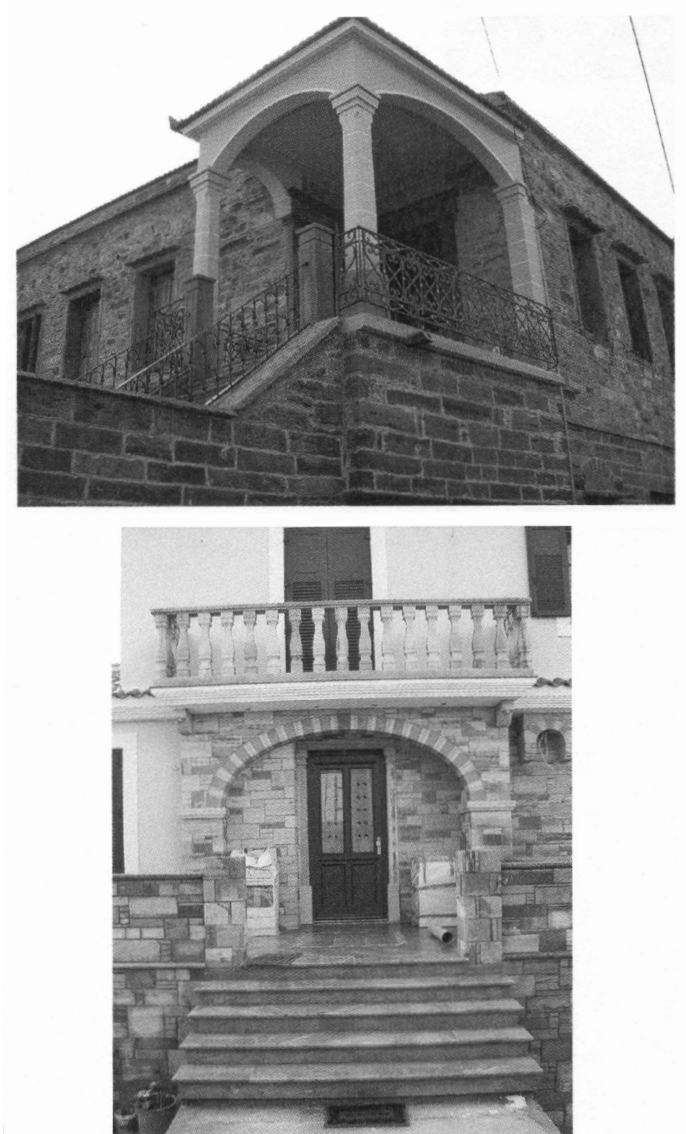

Fig. 9. Various applications of the Thymianá Stone.

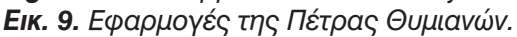

\section{Conclusions}

Based on the relevant data from the petrographic - mineralogical examination of samples, their chemical assays, and the determination of the various physical mechanical properties of the different commercial types of the Thymianá Stone, the following conclusions can be drawn:

a. All the rocks studied under the generic name "Pétra Thymianón" (= Thymianá Stone) are mainly fine-grained clastic sediments of the pelite group. In some cases, at sites, they become coarser-grained and grade down into fine-grained sandstone. The term
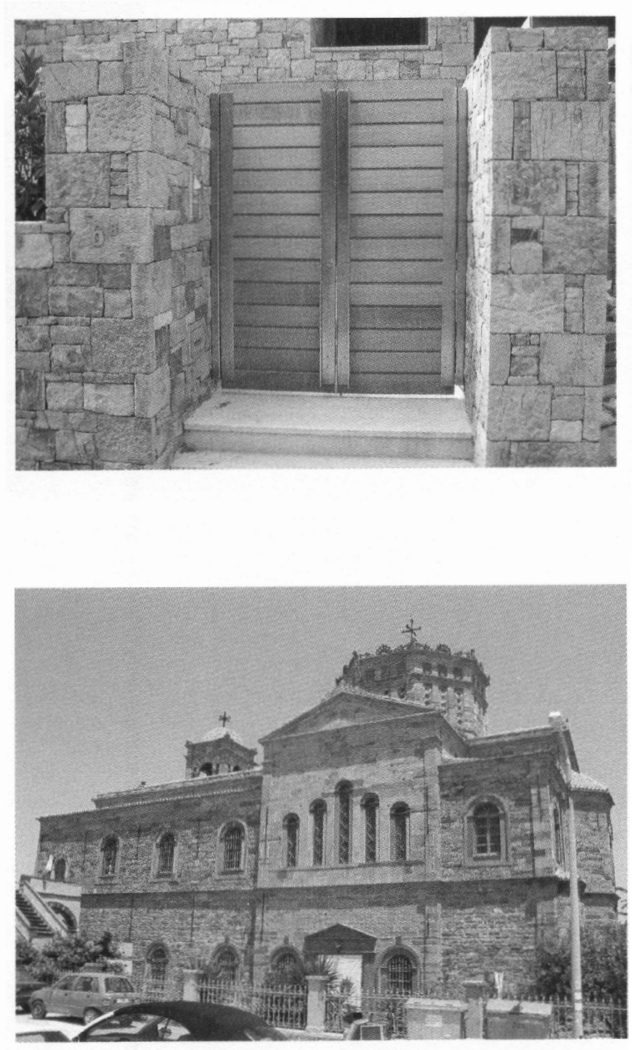

"pelite" is used simply to characterize grain size and refers to clastic sediments with grains less than 0.063 $\mathrm{mm}$.

b. In addition to quartz, all types of the Thymianá Stone contain varying and significant pecentages of other minerals, such as leaf-shaped minerals, carbonates (ankerite, dolomite, calcite) and iron oxides - hydroxides (hematite, goethite, limonite). The latter give to the stone its nut-brown to orange colour. Due to their increased content in carbonate and iron minerals, these stones are classified as carbonaceous - ferruginous pelites. 
c. The four commercial types of the Thymianá Stone are slightly different in colour, grain size, mineralogical assay, form and distribution of iron oxides - hydroxides, but these differences are not significant to suggest a change in lithologic facies.

d. The increased values of open porosity and, hence, water absorption together with the presence of leafshaped and clay minerals render the stone susceptible to weathering. This may cause the appearance of intense staining on its surface, should the stone be used for external applications in wet climates presenting a wide range of temperature fluctuations. In such a case, care for proper protection or maintenance should be taken.

e. The orientation of the leaf-shaped minerals observed in the stone reveals that it has undergone some very low degree of metamorphism after diagenesis.

f. Concerning the "Malaki" type of the stone, the nature of the material with its significant quartz and leafshaped minerals content in combination with the alternating thin horizons of the various lithologic facies causes problems during the cutting process; it "jams" as the quarrymen say. This is due to fact that cutting equipment free quartz grains during the process that together with the leafshaped minerals produce increased amounts of mud. To face this situation, the quantity of water used in cut- ting has to be significantly increased, care must be taken to alternate hard blocks with softer ones and the use of appropriate for this kind of stones cutting equipment is necessary.

\section{Acknowledgements}

The authors would like to acknowledge the contribution of the following I.G.M.E. colleagues (current and retired): Mr. N. Papaioannou (LITHOS Laboratory), Head of the Scientific Research Project, Mrs. S. Karandasi (Mineralogy - Petrology Section) for carrying out the mineralogical and petrographic examinations, Mr. S. Philippou (Analytical Laboratories Section) for the various chemical analyses, and Mr. I. Kousseris (LITHOS Laboratory) for performing the tests to determine the physical mechanical properties of the various "Pétra Thymianón" types.

\section{References}

Besenecker, H., Durp, S., Herget, G., Kauffmann, G., Ludtke, G., Roth, W., Tietze, K.W., 1971. Geological Map of Chios Island (North and South Part), Scale 1:50000. Edition: Hellenic Institute of Geological Substratum Research (I.G.S.R.).

Papaioannou, N., Laskaridis, K., Patronis, M., Karandasi, S., Kousseris, I., 2006. Evaluation of Quality Characteristics and Quantity Parameters for the Structural Stones of Greece. Administrative Study. Report on Thymianá Region, Chios Island. Institute of Geology and Mineral Exploration (I.G.M.E.), Athens, 20 p. [in Greek]. 